\title{
A Review of the Stratigraphy of the Ogallala Formation and Revision of Neogene ("Tertiary”) Nomenclature in Kansas
}

\author{
Greg A. Ludvigson ${ }^{1,2}$, Robert S. Sawin ${ }^{1,2}$, Evan K. Franseen ${ }^{1,2}$, \\ W. Lynn Watney ${ }^{1,2}$, Ronald R. West ${ }^{2,3}$, and Jon J. Smith ${ }^{1}$
}

\begin{abstract}
${ }^{1}$ Kansas Geological Survey, 1930 Constant Avenue, Lawrence, Kansas 66047
${ }^{2}$ Member, Stratigraphic Nomenclature Committee, Kansas Geological Survey

${ }^{3}$ Emeritus Professor, Kansas State University, Manhattan, Kansas 66506
\end{abstract}

\begin{abstract}
The member names for the Ogallala Formation (including the Valentine, Ash Hollow, and Kimball) in Kansas of Zeller (1968) are abandoned. The Ogallala Formation in Kansas includes strata of Miocene and earliest Pliocene age, revising earlier correlation to the Pliocene only (Zeller, 1968). The Kansas Geological Survey is abandoning use of the term “Tertiary," to be replaced by the term "Neogene.” International stage boundaries for the Neogene have not been established in Kansas.
\end{abstract}

\section{Introduction}

The Ogallala Formation is the only named rock unit of Neogene ("Tertiary”) age recognized in Kansas. The unit was originally named by Darton (1899) from exposures in western Nebraska. Zeller (1968) placed the Ogallala Formation in the Pliocene Stage/Epoch; however, more recent work suggests the Ogallala is mostly Miocene and earliest Pliocene in age. Also in question is the validity of member names (Valentine, Ash Hollow, and Kimball) in the Ogallala Formation of Kansas because of the depositional nature of the Ogallala, and the distant location of the type sections in Nebraska. Finally, the international community has replaced the term "Tertiary" as a system/period name with, in ascending order, the Paleogene and Neogene. The Ogallala Formation is Neogene in age; Paleogene rocks do not occur in Kansas.

This paper outlines Neogene (“Tertiary”) nomenclature changes to Zeller (1968) that are now formally adopted by the Kansas Geological Survey (KGS).

\section{Lithostratigraphy of the Ogallala Formation}

The deposits in the Ogallala Formation accumulated as an apron of clastic sediments that were shed eastward from the uplifting Rocky Mountains. Also included in the succession are autochthonous sediments such as lacustrine marls, primary air-fall volcanic tuffs, and intraclastic conglomerates. Seni (1980) interpreted Ogallala strata in northern Texas to have accumulated by the coalescence of lobate alluvial fans that each aggraded from widely spaced trunk streams discharging from highlands west of the Rocky Mountain front. Given the current uncertainties in (1) precise local tectonic histories for each catchment basin, (2) variations in the local timing of sediment trapping and overtopping spillover from closed intermontaine basins within the north-south length of the Rocky Mountain source area, and (3) local differences in denudation rates, the rates of aggradation and the sedimentary provenance of trunk stream systems issuing from the mountain front (Chapin, 2008; Flowers et al., 2008; Eaton, 2008), the trunk streams feeding the depositional system of the Ogallala Formation all probably experienced unique histories. Consequently, little logical support exists for an expectation of regional lithostratigraphic continuity along the north-south extent of the Ogallala Formation.

Moore et al. (1944) and Frye et al. (1956) adopted member names of the Ogallala Formation in Kansas that were originally designated in the type area of Nebraska (Lugn, 1939). In ascending order, these are the Valentine, Ash Hollow, and Kimball Members, each with characteristic lithofacies associations. Whereas these lithofacies are regionally widespread in Nebraska and Kansas, they do not appear in a consistent stratigraphic stacking order. Reports by Frye et al. (1956) in Kansas, Swinehart (1974) in Nebraska, Thomasson (1979, p. 6, 9) in Kansas, and Diffendal (1982, p. 965) in Nebraska clearly state that while deposits resembling the Valentine, Ash Hollow, and Kimball Members are recognized over a broad geographic area, they do not occur in any consistent stratigraphic order. Although they might be valid lithostratigraphic units where they were defined in the local type area, their lateral continuity has never been demonstrated, and they should not be considered valid lithostratigraphic units outside of that type area. They should not be considered valid lithostratigraphic units in Kansas.

Skinner et al. (1968) named the Cap Rock Member of the Ash Hollow Formation, reviving the use of a colloquial term for calcrete escarpments that are common landscape features throughout the outcrop area of the Ogallala Formation. Diffendal (1982) pointed out that there is a common misconception of the Cap Rock as a single regionally widespread thick terminal calcrete defining the High Plains 
surface. The concept of the Cap Rock as a unique stratigraphic entity has not been supported by stratigraphic studies of the Ogallala Formation, which has been shown to contain thick calcrete beds that occur in numerous stratigraphic positions (Diffendal, 1982). The “Cap Rock” has also had local colloquial usage in Kansas, but does not refer to a unique depositional unit of widespread lateral extent. It is, rather, a term for a geomorphic feature.
In Kansas, the term “algal limestone” has historically been applied to calcretes capping exposures of the Ogallala Formation, with past inferences about supposed regional stratigraphic continuity. Swineford et al. (1958) showed that these deposits throughout the High Plains region are not lacustrine deposits, but calcretes that accumulated through pedogenic processes. Correlations among calcrete beds in the Ogallala Formation of Kansas are not known at present.

\section{Chronostratigraphy of the Ogallala Formation}

\section{Fossil Mammalian Biostratigraphy}

The widely used concept of the North American Land Mammal Ages (NALMAs) was first codified by Wood et al. (1941), referring to intervals of Cenozoic time with characteristic assemblages of terrestrial vertebrate fossils. In the original proposed formulation, the Clarendonian, Hemphillian, and Blancan NALMAs were all included in the Pliocene Series (Wood et al., 1941), but refinements in geochronology have since moved the Clarendonian and Hemphillian downward into the Miocene Series (fig. 1). Evernden et al. (1964) provided the first geochronologic validation of the general temporal order of the NALMA biochronologic scheme. Additional refinements and discussion about the importance of diachroneity in the application of NALMAs are still continuing (Woodburne, 1977, 1996; Lindsay et al., 1984; Lindsay, 1995; Alroy, 1998; Walsh, 2005). Alroy (2000) specified the chronological boundaries and ranges of the NALMAs used in fig. 1. Diffendal (1982) was able to broadly correlate deposits within in the Ogallala Formation by use of the Clarendonian and Hemphillian North American land mammal ages, and used this biostratigraphy to define two mappable unconformity-bounded units.

For the state of Kansas, published descriptions of vertebrate fossil assemblages have included elements of Pleistocene faunas ( Irvingtonian North American land mammal age), Pliocene faunas ( Blancan North American land mammal age), and Miocene faunas ( Hemphillian, Clarendonian, and Barstovian North American land mammal ages). This literature clearly shows that the Ogallala Formation in Kansas contains Miocene fossils (fig. 1).
Irvingtonian Faunas in Kansas (1.8-0.3 Ma) Recent descriptions of Irvingtonian faunas in Kansas are presented in Martin et al. (2003, 2008), and Bell and Repenning (1999).

Blancan Faunas in Kansas (4.9-1.8 Ma) Descriptions of Blancan faunas in Kansas have been presented by Martin et al. (2002, 2003, 2008), Emslie (2007), Zakrzewski (1981, 1991), and Eshelman (1975).

Hemphillian Faunas in Kansas (10.3-4.9 Ma) Examples of descriptions of Hemphillian biotas in Kansas are presented in Thomasson (1979), Thomasson et al. (1990), Liggett (1997), Wallace (1997), and Mullin (2005). Zakrzewski (1990) reported that the Bemis local fauna of Ellis County and the Minium Quarry local fauna of Graham County in Kansas contain taxa that are placed in the Hemphillian land mammal age.

Clarendonian Faunas in Kansas (13.6-10.3 Ma) Examples of descriptions of Clarendonian faunas in Kansas are presented in Steadman (1981), Lim and Martin (2001), and Bartley (2005). Zakrzewski (1990) reported that the Keller local fauna of Ellis County, Kansas, contains taxa that are placed in the Clarendonian land mammal age.

\section{Barstovian Faunas in Kansas (16.3-13.6 Ma) Zakrzewski} (1990) reported that the Gretna local fauna of Phillips County, Kansas, and the Hamburg local fauna of Ellis County, Kansas, contain taxa that are placed in the Barstovian land mammal age. He also noted that the Hamburg local fauna might range up into the early Clarendonian (Zakrzewski, 1990).

FIGURE 1 (following page)—Summary of biostratigraphic and tephrochronologic data indicating the Miocene age of the Ogallala Formation in Kansas. Neogene series boundaries are adopted from the International Commission on Stratigraphy (posted August 2009). Magnetic polarity chron data are from Gradstein et al. (2004); black = normal; white = reversed. The ranges of the North American Land Mammal Ages (NALMAs) are after Alroy, 2000. Color coding of the ranges of the Hemphillian, Clarendonian, and Barstovian NALMAs suggests that the oldest Neogene strata in Kansas possibly range back to the Lower or Middle Miocene. Color coding of chemical fingerprinting matches between volcanic ashes in the Ogallala Formation of northern Kansas with tuffs from the Bruneau-Jarbidge, Twin Falls, and Picabo volcanic fields in the Snake River Plain volcanic province in southern Idaho (12.7 to 6.7 Ma; Perkins, 1998) similarly suggests that the oldest Neogene strata in Kansas range back to the Middle Miocene. This conclusion is further supported by an 11.5-Ma fissiontrack date reported from the Calvert Mine ash in Norton County, Kansas, and a newly reported chemical fingerprinting match to the 11.93 Ma Ibex Peak Tuff from a volcanic ash bed in Smith County, Kansas. If the reported 18 Ma K-Ar date on the volcanic ash in Ellis County (Thomasson, 1979) proves to be correct, then the Ogallala Formation in Kansas ranges back into the Lower Miocene. The boundaries for the Lower, Middle, and Upper Miocene Subseries are based on the following sources: base of the Pliocene Series (5.332 Ma) is from Van Couvering et al. (2000); base of Upper Miocene Subseries (11.608 Ma) is from Hilgen et al. (2005); base of Middle Miocene Subseries (15.97 Ma) is from the most recent estimates of the base of the Langhian Stage from http://stratigraphy.science.purdue.edu/gssp/, June 30, 2009; and Harland et al. (1990); and base of the Miocene Series (23.03 Ma) is from Steininger et al. (1997). 


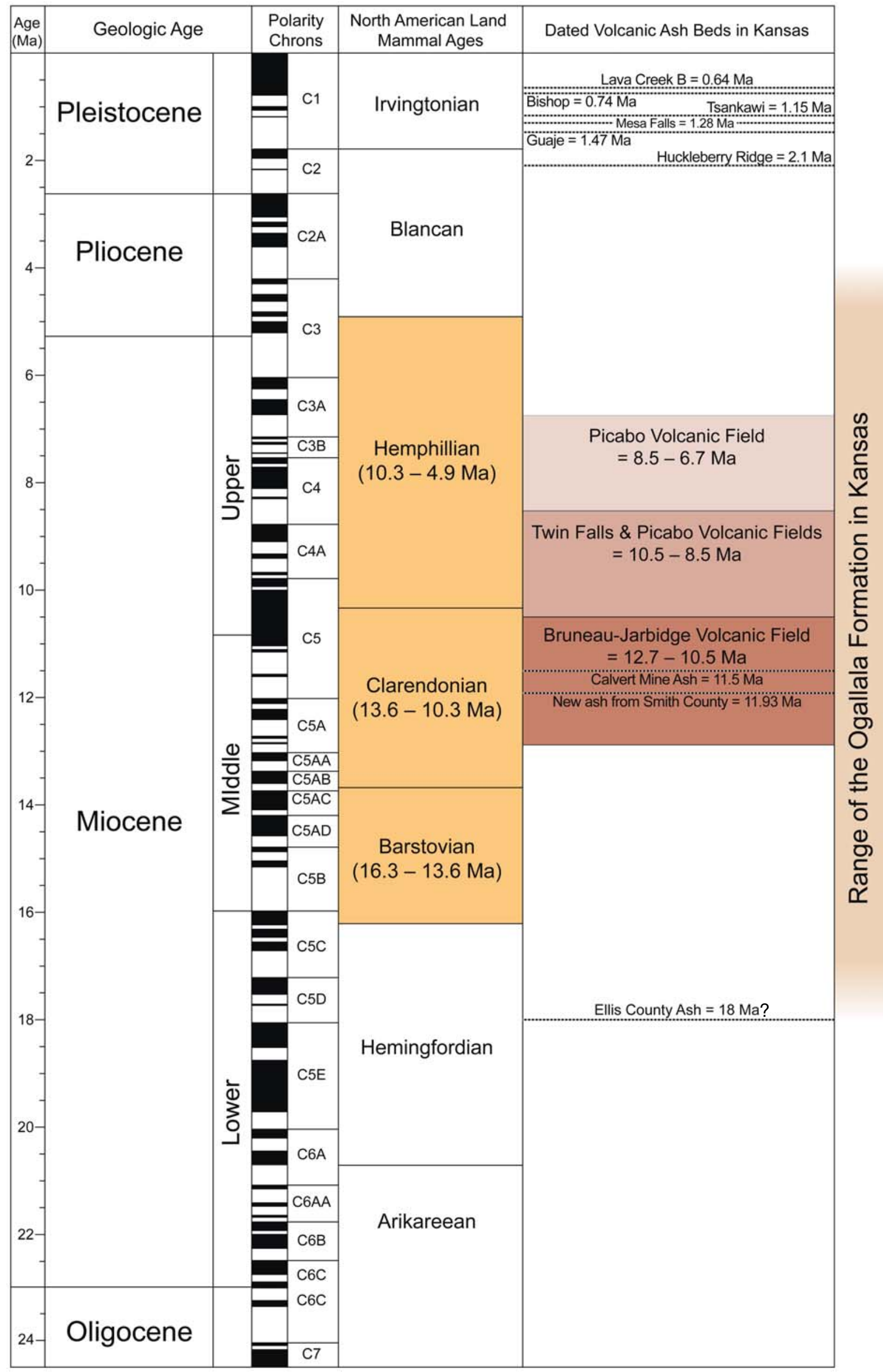




\section{Paleobotanical Biostratigraphy}

Biostratigraphic zonations of fossil flora from the Ogallala Formation have been published by Elias (1942), Frye et al. (1956), Frye and Leonard (1959), and Thomasson (1979, 1990). Thomasson $(1979,1990)$ showed that earlier floral biostratratigraphic schemes that had been correlated with lithostratigraphic members of the Ogallala Formation (i.e. Valentine, Ash Hollow, Kimball) are incorrect. However, Thomasson (1990) indicated that fossil grasses of the genus Berriochloa do appear to record a valid biostratigraphic succession; B. communis and B. primaeva appear exclusively in Clarendonian strata, while B. amphoralis, B. conica, B. dartoni, B. glabra, B. graceii, B. inflata, B. maxima, B. minuta, B. pumila, B. tuberculata and B. variegata appear exclusively in Hemphillian strata. These interpretations have been further supported by more recent studies in Kansas and Nebraska (Thomasson, 2005; Darnell and Thomasson, 2007).

\section{Volcanic Ash Bed Tephrochronology}

Frye et al. (1956) reported the presence of six distinctive volcanic ash beds in the Ogallala Formation of northern Kansas, one of which included a thick ash at the Calvert Mine in Norton County. This observation was followed by Boellstorff (1978), who reported 11 unique Miocene fissiontrack ages from volcanic ash beds from the "Ogallala Group" in the Great Plains, and Diffendal (1982), who reported at least five superposed volcanic ash beds in exposures of the Ogallala.

Other reports on Cenozoic volcanic ash deposits in Kansas appeared in Swineford and Frye (1946), Carey et al., (1952), Swineford et al. (1955), Naeser et al. (1973), Boellstorff (1976, 1978), Izett and Wilcox (1982), Carter et al. (1990), Ward et al. (1993, 1998), Perkins et al. (1995a), and Perkins (1998).

Volcanic ash beds from the High Plains in western Kansas are distal air-fall tuffs that have been significantly sorted to fine-grained micron-scale rhyolitic glass bubble-wall shards by long-distance atmospheric transport (Rose et al., 2003). Dating of these distal ash fall deposits poses special technical challenges, as the primary zircon and sanidine phenocrysts that are a preferred substrate for radiometric dating are rarely present in distal sites, and the possibility of local detrital contamination of mineral grain populations by fluvial transport is a significant concern. Boellstorff $(1976,1978)$ and other authors have published radiometric fission-track dates from glass shards in volcanic ashes from the High Plains, although the precision of this dating technique is compromised by accelerated annealing of fission tracks in glasses as opposed to crystalline solids (Naeser et al., 1973). Alternatively, chemical fingerprinting of distal volcanic ash deposits by electron probe microanalyses of glass shards has established close matches to well-dated proximal volcanic tuffs (Perkins et al., 1995a, b; Perkins, 1998).

Miocene Volcanic Ash Bed Dates from the Ogallala Formation Boellstorff $(1976,1978)$ reported Miocene volcanic ash bed ages based on fission-track dating of volcanic glass shards, ranging between $10.6 \pm 0.6 \mathrm{Ma}$ to $5.0 \pm 0.2 \mathrm{Ma}$ from units in the upper part of the Ogallala Formation in Nebraska and Texas. Importantly, Boellstorff $(1976,1978)$ noted that these ash dates were at odds with prevailing ideas about the succession of units in the Ogallala Group, and that some Miocene ash beds occurred in units that previously had been considered to be Pleistocene in age. More recently, Perkins et al. (1995) reported that the Ash Hollow Formation (upper Ogallala Group) in Nebraska, northwest Kansas, and southern South Dakota contains Miocene volcanic ash beds ranging in age from 12.5 Ma to 6.5 Ma.

Cenozoic Volcanic Ash Beds in Kansas A brief summary of all known dated volcanic ash beds in the Cenozoic record of Kansas follows.

Lava Creek B Ash Bed (0.64 Ma) This tephra originated from the last major eruption from the Yellowstone volcanic center. Izett and Wilcox (1982) identified this ash bed in Clark, Grant, Lincoln, Logan, McPherson, Meade, Republic, Russell, Seward, and Sheridan counties in Kansas. Ward et al. (1993) identified this ash in Pratt County, Kansas.

Bishop Ash Bed (0.74 Ma) This volcanic tephra originated in California (Izett et al., 1970), and Ward et al. (1993) identified two occurrences of this ash bed in Reno County, Kansas.

Tsankawi Ash Bed (1.15 Ma) This volcanic tephra (Izett, 1981, p. 10,217) originated from the Jemez volcanic field in New Mexico and has been identified by Ward et al. (1993) in Clark, Comanche, and Harper counties in Kansas.

Mesa Falls Ash Bed (1.28 Ma) This volcanic tephra originated from the Yellowstone volcanic center (Izett and Wilcox, 1982). Ward et al. (1993) identified an occurrence of this ash bed in Pratt County, Kansas.

Guaje Ash Bed (1.47 Ma) This volcanic tephra originated from the Jemez volcanic field in New Mexico (Izett, 1981, p. 10,217), and Ward et al. (1993) identified an occurrence of this ash bed in Pratt County, Kansas.

Huckleberry Ridge Ash Bed (2.1 Ma) This volcanic tephra originated from the Yellowstone volcanic center (Izett and Wilcox, 1982). Izett and Wilcox (1982) identified occurrences of this ash bed in McPherson and Meade counties, Kansas.

Ash Beds from the Picabo Volcanic Field (8.5-6.7 Ma) The Upper Miocene Picabo volcanic field is part of the Neogene Snake River Plain volcanic province in southern Idaho and was an earlier manifestation of the northeastward migration of the Yellowstone Hot Spot (Perkins et al., 1995b). On the basis of chemical fingerprinting of volcanic glass shards, Perkins (1998, p. 185) tentatively identified two volcanic ash fall occurrences in northwest Kansas that probably originated from the Picabo volcanic field. 
Ash Beds from the Twin Falls and Picabo Volcanic Fields (10.5-8.5 Ma) The Upper Miocene Twin Falls and Picabo volcanic fields were both parts of the Neogene Snake River volcanic province in southern Idaho, and both were expressions of the northeastward migration of the Yellowstone Hot Spot (Perkins et al., 1995b). On the basis of chemical fingerprinting of volcanic glass shards, Perkins (1998, p. 186) identified four volcanic ash fall occurrences in northwest Kansas that probably originated from either one or both of these volcanic fields.

Ash Beds from the Bruneau-Jarbidge Volcanic Field (12.710.5 Ma) The Middle-Upper Miocene Bruneau-Jarbidge volcanic field is another part of the Neogene Snake River Plain volcanic province in southern Idaho and was also part of the northeastward track of the Yellowstone Hot Spot (Perkins et al., 1995b). On the basis of chemical fingerprinting of volcanic glass shards, Perkins (1998, p. 186) identified one ash fall occurrence in northwest Kansas that probably originated from the Bruneau-Jarbidge volcanic field. Two documented occurrences of eruptive tephra from the Bruneau-Jarbidge volcanic field in Kansas are:

Calvert Mine Ash Bed (11.5 Ma) This Upper Miocene volcanic ash bed in Norton County, Kansas, was identified by Carey et al. (1952) and Frye et al. (1956). Potter (1991) reported a fission-track date

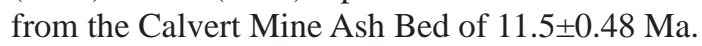

\section{Newly fingerprinted Ash Bed from Smith} County (11.93 Ma) This Middle Miocene volcanic ash bed was recently analyzed by the USGS Tephrochronology Laboratory in Menlo Park, California. On the basis of chemical fingerprinting of volcanic glass shards, this sample (database number 5599) most closely matches the Tuff of Ibex Peak (11.93 $\pm 0.03 \mathrm{Ma})$ in the Trapper Creek Section of southern Idaho (personal communication from analyst Elmira Wan, 2008). This volcanic ash fall occurrence originated from the Bruneau-Jarbidge volcanic center (see Perkins et al., 1995b). Of special note: this volcanic ash bed exposure occurs beyond the currently mapped erosional limit of the Ogallala Formation in Kansas (Kansas Geological Survey, 2008), showing that lithologic criteria for recognition of the unit in this area are in need of revision.

\section{Lower Miocene Ash Bed in Ellis County (18 Ma)?}

Thomasson (1979, p.6) reported a K-Ar date on a volcanic ash

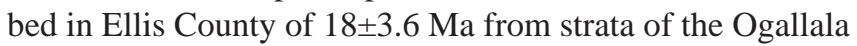
Formation. Major uncertainties about the reliability of this date exist, and a reevaluation using newer radiometric or chemical fingerprinting techniques is warranted. The occurrence of at least five species of Berriochloa at this site suggests that the strata are Upper Miocene in age (Thomasson, 2005; Darnell and Thomasson, 2007).

\section{Is There A Miocene-Pliocene Unconformity in the Great}

Plains? On the basis of a $5.0 \pm 0.2$ to $2.8 \pm 0.3$ Ma gap in the ages of dated volcanic ash beds in the Great Plains, Boellstorff $(1976,1978)$ postulated the existence of a regional hiatus in the Great Plains spanning most of the Pliocene Series. This idea was recently supported by Chapin (2008), who argued that an Upper Miocene cessation of regional fluvial aggradation in the southwestern U.S. was related to intensification of the North American monsoon, a result of the plate-tectonic opening of the Gulf of California. This change in seasonal rainfall patterns triggered a regional episode of fluvial incision throughout the southwestern U.S. (Chapin, 2008). If true, this argument suggests that Pliocene strata are largely missing from the High Plains of western Kansas.

One important exception to this generalization comes from the Meade basin in southwestern Kansas. A recent integration of volcanic ash bed chronology and newer paleomagnetic data (strata ranging from polarity chrons C3 to C1, fig. 1) by Martin et al. (2008) suggests that units spanning through the purported hiatus may be contained in Pliocene strata of the Rexroad, Ballard, and Crooked Creek formations (Zakrzewski, 1988), all of which overlie the Ogallala Formation in the Meade basin in Meade County, Kansas. This basin coincides with an area of local sediment accommodation that may have been influenced by significant evaporite karst formed in underlying Permian strata. Evaporite dissolution and locally thickened Neogene strata (Macfarlane, 2009) abruptly developed west of the Crooked Creek fault of Frye (1950), a north-south trending linear feature. Izett and Honey (1995) suggested that all the local Pliocene subsidence in the Meade basin can be attributed to evaporite dissolution. Reports of Blancan faunas from other areas in Kansas (Eshelman, 1975; Zakrzewski, 1991) suggest that Pliocene strata also occur elsewhere in the state, but the regional extent of these deposits is poorly known at present.

\section{Summary}

On the basis of published descriptions of fossil land mammals and plants from the Barstovian, Clarendonian, and Hemphillian land mammal ages, and published radiometric dates from volcanic ash beds ranging from 18 to $5 \mathrm{Ma}$, strata from the Ogallala Formation in Kansas are Miocene in age and range up into the earliest Pliocene. 


\section{Neogene (“Tertiary”) System/Period Nomenclature}

The term Tertiary was originally used by Giovanni Arduino (1759) who proposed that geologic time be divided into three orders: the Primary, Secondary, and Tertiary. The Primary and Secondary-terms that have long been obsolete-were approximately equal to today's Paleozoic and Mesozoic Erathems/Eras. Only the term Tertiary has survived; however, the boundary between the Tertiary and Quaternary has never been formally defined.

Beginning in 1989, the International Commission on Stratigraphy (ICS) of the International Union of Geological Sciences (IUGS) discontinued the use of the term Tertiary and divided the Cenozoic Erathem/Era into the Paleogene (Naumann, 1866), Neogene (Hörnes, 1853), and Quaternary (Desnoyers, 1829) Periods/Systems (Cowie and Bassett, 1989; fig. 1). Subsequent ICS/IUGS time scales (Remane, 2000; Gradstein, Ogg, and Smith, 2004; Gradstein, Ogg, Smith, et al., 2004; Ogg et al., 2008) continued this trend. Others (e.g., Berggren et al., 1995; Gradstein and Ogg, 1996; Berggren, 1998) have also published charts that excluded the Tertiary. Tertiary is absent from the International Stratigraphic Chart on the ICS website (http://www.stratigraphy.org/upload/ ISChart2009.pdf, 02 December 2009); a footnote on a previous version of the chart (http://www.stratigraphy.org/ upload/ISChart2008.pdf, 30 June 2009) stated “The historic
‘Tertiary’ comprises the Paleogene and Neogene, and has no official rank.”

Attempts have been made to revive the term Tertiary, most recently by Salvador (2006a, b) and Head et al. (2008). Head et al. (2008) point out that "it [Tertiary] has never been officially eliminated by the IUGS.”

The KGS has adopted the ICS/IUGS's current position on the use of the system/period name Neogene and has abandoned the term Tertiary (fig. 2).

\section{International Stage/Age Names}

An approximate range from 18 to $5 \mathrm{Ma}$ for Neogene strata in Kansas includes, in ascending order, the international Miocene stages/ages Burdigalian, Langhian, Serravallian, Tortonian, and Messinian, and the Pliocene stage/age Zanclean (fig. 2). The basal boundaries of the Serravallian, Tortonian, and Messinian, and Zanclean have been established and ratified by the ICS/IUGS (see http://www.stratigraphy.org/ upload/ISChart2008.pdf); ratification of the basal boundaries of the Burdigalian and Langhian is expected soon. The locations of Miocene-Pliocene stage/age boundaries in the Kansas section have not been established, and therefore, are not valid in Kansas.
Zeller, 1968

\begin{tabular}{|c|c|c|c|c|}
\hline Members & Formations & $\begin{array}{l}\stackrel{\oplus}{0} \\
\underset{\varpi}{\sim}\end{array}$ & 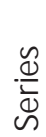 & $\underbrace{\frac{\varepsilon}{d}}_{\text {जी }}$ \\
\hline Kimball & \multirow{3}{*}{ Ogallala } & & \multirow{3}{*}{ 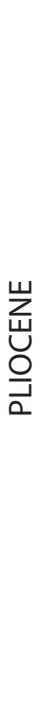 } & \\
\hline Ash Hollow & & & & $\frac{r}{\frac{r}{\sigma}}$ \\
\hline Valentine & & & & \\
\hline
\end{tabular}

KGS Nomenclature, 2009

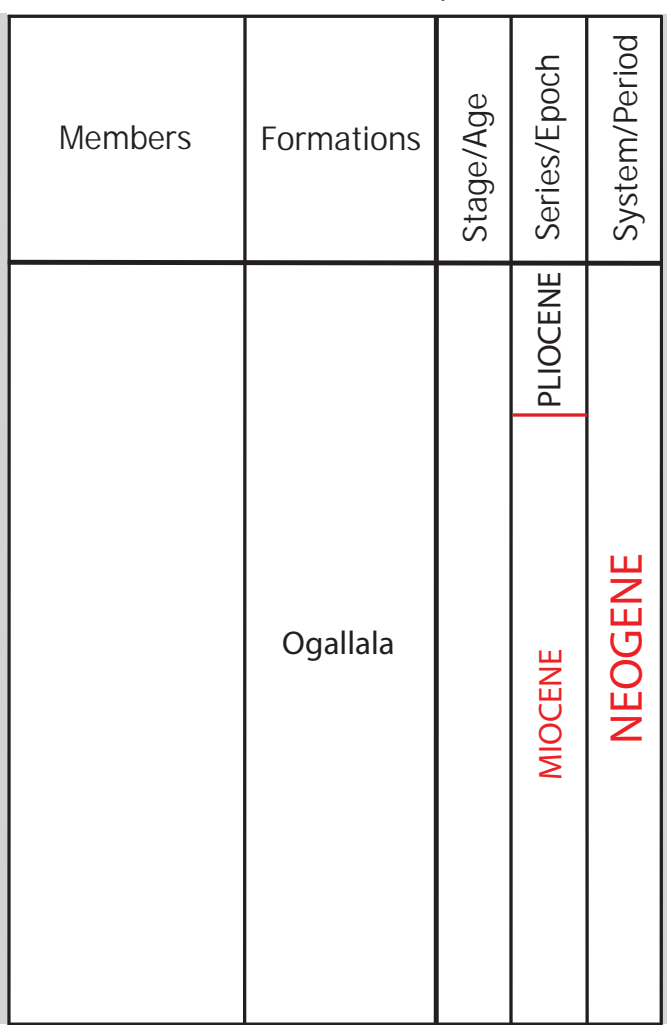

ICS Nomenclature

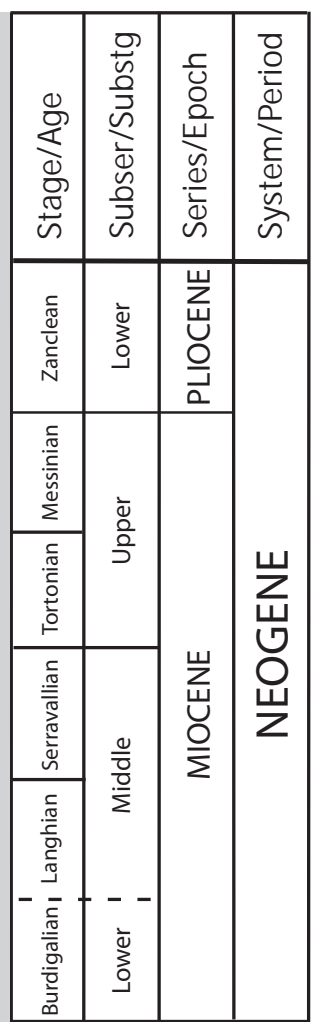

FIGURE 2-Neogene nomenclature changes to Zeller (1968) that are formally adopted by the Kansas Geological Survey. Left column: Zeller (1968). Center column: This paper, changes are highlighted in red. Note abandoned member names are not shown. Right column: ICS nomenclature; stage/age names are shown in relative position. 


\section{Summary of Formally Adopted Neogene Stratigraphic Nomenclature Changes}

The following changes are adopted by the Kansas Geological Survey (see fig. 2):

1. The Ogallala Formation is Miocene and earliest Pliocene in age, and Zeller (1968) is revised accordingly.

2. Ogallala Formation member names (Valentine, Ash Hollow, and Kimball) of Zeller (1968) are abandoned.

3. The system/period term Tertiary of Zeller (1968) is abandoned and replaced with Neogene.

4. International stage/age boundaries have not been established in Kansas. Therefore, international stage/age nomenclature will not be adopted in Kansas at this time.

\section{Acknowledgments}

The authors thank Drs. Joe R. Thomasson, Bill C. Johnson, and Larry D. Martin for constructive reviews that improved the clarity of our discussion. Thanks to Drs. David L. Fox and Richard J. Zakrzewski for sharing published and unpublished information, and to Elmira Wan of the USGS Tephrochronology Laboratory for the report on the volcanic ash bed in Smith County, Kansas. Marla Adkins-Heljeson is thanked for editorial and publication assistance.

\section{References}

Alroy, J., 1998, Diachrony of mammalian appearance eventsImplications for biochronology: Geology, v. 26, p. 23-26.

Alroy, J., 2000, New methods for quantifying macroevolutionary patterns and processes: Paleobiology, v. 26, p. 707-733.

Arduino, G., 1759, Lettera seconda sopre varie osservazioni fatti in diversi parti del territorio di Vicenza, ed altrove, appartenenti alla teoria terrestre, ed alla mineralogía. Venezia.

Bartley, K. J., 2005, A taphonomic study of Clarendonian (Miocene) Teleoceras (Perissodactyla, Rhinocerotoidea) from the Ogallala Formation, northwestern Kansas: M.S. thesis, State University of New York at Buffalo, 122 p.; American Geological Institute, GeoRef Accession No. 2007-041818.

Bell, C. J., and Repenning, C. A., 1999, Observations on dental variation in Microtus from the Cudahy ash pit fauna, Meade County, Kansas and implications for Irvingtonian microtine rodent biochronology: Journal of Vertebrate Paleontology, v. 19, p. 757-766.

Berggren, W. A., Hilgen, F. J., Langereis, C. G., Kent, D. V., Obradovich, J. D., Raffi, I., Raymo, M. E., and Shackleton, N. J., 1995, Late Neogene (Pliocene-Pleistocene) chronologyNew perspectives in high-resolution stratigraphy: Geological Society of America Bulletin, v. 107, no. 11, p. 1,272-1,287.

Berggren, W. A., 1998, The Cenozoic Era—Lyellian (chrono) stratigraphy and nomenclatural reform at the millennium; in, The Past is the Key to the Present, D. J. Blundell and A. C. Scott, eds.: Geological Society, London, Special Publications 143, p. 111-132; also reprinted in 2005 in Stratigraphy, v. 2, no. 1, p. $1-12$.

Boellstorff, J., 1976, The succession of late Cenozoic volcanic ashes of the Great Plains-A progress report; in, Guidebook, 24 ${ }^{\text {th }}$ Annual Meeting of the Midwestern Friends of the Pleistocene, C. K. Bayne, ed.: Kansas Geological Survey, Guidebook Series 1, p. 37-71.

Boellstorff, J., 1978, Chronology of some late Cenozoic deposits from the central United States and the Ice Ages: Transactions of the Nebraska Academy of Science, v. 6, p. 35-49.

Carey, J. S., Frye, J. C., Plummer, N., and Swineford, A., 1952, Kansas volcanic ash resources, Kansas Geological Survey, Bulletin 96, 68 p.

Carter, B. J., Ward, P. A., III, and Shannon, J.T., 1990, Soil and geomorphic evolution within the Rolling Red Plains using
Pleistocene volcanic ash deposits: Geomorphology, v. 3, p. 471-488.

Chapin, C. E., 2008, Interplay of oceanographic and paleoclimate events with tectonism during middle to late Miocene sedimentation across the southwestern USA: Geosphere, v. 4, p. 976-991.

Cowie, J. W., and Bassett, M. G., 1989, 1989 global stratigraphic chart with geochronometric and magnetostratigraphic calibration: Episodes, v. 12, no. 2, 1 sheet.

Darnell, M. K., and Thomasson, J. R., 2007, First equid remains from the Late Miocene Prolithospermum jonstonii-Nasella pohlii assemblage zone stratotype locality, Elllis County, Kansas: Transactions of the Kansas Academy of Science, v. 110, p. $10-15$.

Darton, N. H., 1899, Relations of Tertiary formations in the western Nebraska region: American Geologist, v. 23, 94 p.

Desnoyers, J., 1829, Observations sur un ensemble de dépôts marins plus récents que les terrains tertiaries du Bassin de la Seine, et constituant une formation géologique districte-Précédées d'un aperçu de la non-simulanéité des bassins tertiares: Annales scientifiques naturelles, Paris, v. 16, p. 171-214, 402-491.

Diffendal, R. F., Jr., 1982, Regional implications of the geology of the Ogallala Group (upper Tertiary) of southwestern Morrill County, Nebraska, and adjacent areas: Geological Society of America Bulletin, v. 93, p. 964-976.

Eaton, G. P., 2008, Epeirogeny in the southern Rocky Mountains region-Evidence and origin: Geosphere, v. 4, p. 764-784.

Emslie, S. D., 2007, Fossil passerines from the early Pliocene of Kansas and the evolution of songbirds in North America: The Auk, v. 124, p. 85-95.

Elias, M. K., 1942, Tertiary prairie grasses and other herbs from the high plains: Geological Society of America, Special Paper 41, $176 \mathrm{p}$.

Eshelman, R. E., 1975, Geology and paleontology of the Early Pleistocene (Late Blancan) White Rock fauna from north-central Kansas: The Museum of Paleontology, University of Michigan, Papers on Paleontology No. 13, 59 p.

Evernden, J. F., Savage, D. E., Curtis, G. H., and James, G. T., 1964, Potassium-argon dates and the Cenozoic mammalian chronology of North America: American Journal of Science, v. 262, p. 145-198. 
Flowers, R. M., Wenicke, B. P., and Farley, K. A., 2008, Unroofing, incision, and uplift history of the southwestern Colorado Plateau from apatite (U-Th)/He thermochronometry: Geological Society of America Bulletin, v. 120, p. 571-587.

Frye, J. C., 1950, Origin of Kansas Great Plains depressions: Kansas Geological Survey, Bulletin 86, pt. 1, p. 1-20.

Frye, J. C., Leonard, A. B., and Swineford, A., 1956, Stratigraphy of the Ogallala Formation (Neogene) of northern Kansas: Kansas Geological Survey, Bulletin 118, 92 p.

Frye, J. C., and Leonard, A. B., 1959, Correlation of the Ogallala Formation (Neogene) in western Texas with the type localities in Nebraska: University of Texas at Austin, Bureau of Economic Geology, Report of Investigations No. 39, 46 p.

Gradstein, F. M., and Ogg, J. G., 1996, A Phanerozoic time scale: Episodes, v. 19, no. 1-2, p. 3-5.

Gradstein, F. M., Ogg, J. G., and Smith, A. G., 2004, A geologic time scale 2004: Cambridge University Press, 589 p.

Gradstein, F. M., Ogg, J. G., Smith, A. G., Bleeker, W., and Lourens, L. J., 2004, A new geologic time scale, with special reference to Precambrian and Neogene: Episodes, v. 27, no. 2, p. 83-100.

Harland, W. B., Armstrong, R., Cox, A. V., Craig, L., Smith, A., and Smith, D., 1990, A geological time scale 1989: Cambridge University Press, Cambridge, 263 p.

Head, M. J., Gibbard, P., and Salvador, A., 2008, The Tertiary-A proposal for its formal definition: Episodes, v. 31, no. 2, p. 248-250.

Hilgen, F., Aziz, H. A., Bice, D., Iaccarino, S., Krijgsman, W., Kuiper, K., Montanari, A., Raffi, I., Turco, E., and Zachariasse, W.-J., 2005, The global boundary stratotype section and point (GSSP) of the Tortonian Stage (Upper Miocene) at Monte Dei Corvi: Episodes, v. 28, no. 1, p. 6-17.

Hörnes, M., 1853, Mitteilung an Professor Bronn gerichtet: Wien, 3 Oktober 1853. Neues Jahrbuch für Mineralogie, Geologie, Geognosie und Petrefaktenkunde, p. 806-810.

Izett, G. A., 1981, Volcanic ash beds-Recorders of upper Cenozoic silicic pyroclastic volcanism in the western United States: Journal of Geophysical Research, v. 88, p. 10,200-10,222.

Izett, G. A., Wilcox, R. E., Power, H. A., and Desborough, G. A., 1970, The Bishop ash bed-A Pleistocene marker bed in the western United States: Quaternary Research, v. 1, p. 121-132.

Izett, G. A., and Wilcox, R. E., 1982, Map showing localities and inferred distributions of the Huckleberry Ridge, Mesa Falls, and Lava Creek Ash Beds (Pearlette Family Ash Beds) of Pliocene and Pleistocene age in the western United States and southern Canada: U.S. Geological Survey, Map I-1325.

Izett, G. A., and Honey, J. G., 1995, Geologic map of the Irish Flats NE quadrangle, Meade County, Kansas: U.S. Geological Survey, Miscellaneous Investigations Series Map I-2498, 1 sheet, scale $1: 24,000$.

Kansas Geological Survey, 2008, Surficial geology of Kansas: Kansas Geological Survey, Map M-118, 1:500,000 scale.

Liggett, G. A., 1997, The Beckerdite local biota (early Hemphillian) and the first Tertiary occurrence of a crocodilian from Kansas: Transactions of the Kansas Academy of Science, v. 100, p. 101-108.

Lim, J. D., and Martin, L. D., 2001, A new species of Leptarctus (Mustelidae) from the Miocene of Kansas: Neues Jahrbuch fur Geologie und Palaeontologie, Monatshefte 2001(10), p. 633-640.

Lindsay, E. H., 1995, Copemys and the Barstovian/Hemingfordian boundary: Journal of Vertebrate Paleontology, v. 15, p. 357-365.

Lindsay, E. H., Opdyke, N. D., and Johnson, N. M., 1984, BlancanHemphillian land mammal ages and late Cenozoic mammal dispersal events: Annual Reviews of Earth and Planetary Sciences, v. 12, p. 445-488.
Lugn, A. L., 1939, Classification of the Tertiary System in Nebraska: Geological Society of America Bulletin, v. 50, p. 1,245-1,276.

Macfarlane, P. A., 2009, New insights into the hydrostratigraphy of the High Plains aquifer from three-dimensional visualizations based on well records: Geosphere, v. 5, p. 51-58.

Martin, R. A., Honey, J. G., Peláez-Campomanes, P., Goodwin, H. T., Baskin, J. A., and Zakrzewski, R. J., 2002, Blancan lagomorphs and rodents of the Deer Park assemblages, Meade County, Kansas: Journal of Paleontology, v. 76, p. 1,072-1,090.

Martin, R. A., Hurt, R. T., Honey, J. G., and Peláez-Campomanes, P., 2003, Late Pliocene and early Pleistocene rodents from the northern Borchers badlands (Meade County, Kansas), with comments on the Blancan-Irvingtonian boundary in the Meade Basin: Journal of Paleontology, v. 77, p. 985-1,001.

Martin, R. A., Paláez-Campomanes, P., Honey, J. G., Fox, D. L., Zakrzewski, R. J., Albright, L. B., Lindsay, E. H., Opdyke, N. D., and Goodwin, H. T., 2008, Rodent community change at the Pliocene-Pleistocene transition in southwestern Kansas and identification of the Microtus immigration event on the central Great Plains: Palaeogeography, Palaeoclimatology, Palaeoecology, v. 267, p. 196-207.

Moore, R. C., Frye, J. C., and Jewett, J. M., 1944, Tabular description of outcropping rocks in Kansas: Kansas Geological Survey, Bulletin 52, pt. 4, p. 137-212.

Mullin, T. C., 2005, Teleoceras fossiger (Rhinocerotidae; Mammalia) from two late Miocene (early Hemphillian) quarries from Kansas: Geological Society of America, Abstracts with Programs, v. 37, no. 7, p. 133.

Naeser, C. W., Izett, G. A., and Wilcox, R. E., 1973, Zircon fissiontrack ages of Pearlette family ash beds in Meade County, Kansas: Geology, v. 1, p. 187-189.

Naumann, C. F., 1866, Lehrbuch der Geognosie (second edition): Leipzig, Engelmann, v. 3, p. 1-192.

Ogg, J. G., Ogg, G., and Gradstein, F. M., 2008, The concise geologic time scale: Cambridge University Press, $177 \mathrm{p}$.

Perkins, M. E., 1998, Tephrochronologic and volcanologic studies of silicic fallout tuffs in Miocene basins of the northern Basin and Range Province, U.S.A.: Ph.D. dissertation, The University of Utah, Salt Lake City, 206 p.; UMI Dissertation Services, Microform No. 9913253, Ann Arbor, MI.

Perkins, M. E., Diffendal, R. F., Jr., and Voorhies, M. R., 1995a, Tephrochronology of the Ash Hollow Formation (Ogallala Group)-Northern High Plains: Geological Society of America, Abstracts with Programs, v. 27, no. 3, p. 79.

Perkins, M. E., Nash, W. P., Brown, F. H., and Fleck, R. J., 1995b, Fallout tuffs of Trapper Creek, Idaho-A record of Miocene explosive volcanism in the Snake River Plain volcanic province: Geological Society of America Bulletin, v. 107, p. 1,484-1,506.

Potter, S. L., 1991, Geologic characteristics of the Calvert ash bed, Ogallala Group (Miocene), western Kansas: M.S. thesis, Fort Hays State University, Hays, Kansas; American Geological Institute, GeoRef Accession No. 1994-056771.

Remane, J. (compiler), 2000, International stratigraphic chart, with explanatory note: International Union of Geological Sciences and Earth Sciences division of UNESCO, 16 p., 1 plate.

Rose, W. I., Riley, C. M., and Dartevelle, S., 2003, Sizes and shapes of 10-Ma distal fall pyroclasts in the Ogallala Group, Nebraska: Journal of Geology, v. 111, p. 115-124.

Salvador, A., 2006a, A stable Cenozoic geologic time scale is indispensable: Episodes, v. 29, no. 1, p. 43-45.

Salvador, A., 2006b, The Tertiary and the Quaternary are here to stay: American Association of Petroleum Geologists, Bulletin, v. 90, no. 1, p. 21-30.

Seni, S. J., 1980, Sand-body geometry and depositional systems, Ogallala Formation, Texas: University of Texas at Austin, 
Bureau of Economic Geology, Report of Investigations No. 105, $36 \mathrm{p}$.

Skinner, M. F., Skinner, S. M., and Gooris, R. J., 1968, Cenozoic rocks and faunas of Turtle Butte, south-central South Dakota: Bulletin of the American Museum of Natural History, v. 138, article 7, p. 379-436.

Steadman, D. W., 1981, A re-examination of Paleostruthus hacheri (Shufeldt), a late Miocene sparrow from Kansas: Journal of Vertebrate Paleontology, v. 1, p. 171-173.

Steininger, F. F., Aubry, M. P., Berggren, W. A., Biolzi, M., Borsetti, A. M., Cartlidge, J. E., Cati, F., Corfeld, R., Gelati, R., Iaccarino, S., Napoleone, C., Ottner, F., Rögl, F., Roetzel, R., Spezzaferri, S., Tateo, F., Villa, G., and Zevenboom, D., 1997, The global stratotype section and point (GSSP) for the base of the Neogene: Episodes, v. 20, no. 1, p. 23-28.

Swineford, A., and Frye, J. C., 1946, Petrographic comparison of Pliocene and Pleistocene volcanic ash from western Kansas: Kansas Geological Survey, Bulletin 64, pt. 1, p. 1-32.

Swineford, A., Frye, J. C., and Leonard, A. B., 1955, Petrography of the late Tertiary ash falls in the central Great Plains: Journal of Sedimentary Petrology, v. 25, p. 243-261.

Swineford, A., Leonard, A. B., and Frye, J. C., 1958, Petrology of the pisolitic limestone in the Great Plains: Kansas Geological Survey, Bulletin 130, pt. 2, p. 97-116.

Swinehart, J. B., 1974, Ogallala stratigraphy of southwest Nebraska-A proposal: Nebraska Academy of Science Program, p. 36-37.

Thomasson, J. R., 1979, Late Cenozoic grasses and other angiosperms from Kansas, Nebraska, and ColoradoBiostratigraphy and relationships to living taxa: Kansas Geological Survey, Bulletin 218, 68 p.

Thomasson, J. R., 1990, Fossil plants from the late Miocene Ogallala Formation of central North America-Possible paleoenvironmental and biostratigraphic significance; in, Geologic Framework and Regional Hydrology-Upper Cenozoic Blackwater Draw and Ogallala Formations, Great Plains, T. C. Gustavson, ed.: University of Texas at Austin, Bureau of Economic Geology, Symposium Publication No. 6, p. 99-114.

Thomasson, J. R., 2005, Berriochloa gabeli and Berriochloa huletti (Gramineae:Stipeae), two new grass species from the late Miocene Ash Hollow of Nebraska and Kansas: Journal of Paleontology, v. 79, p. 185-199.

Thomasson, J. R., Zakrzewski, R. J., LaGarry, H. E., and Mergen, D. E., 1990, A late Miocene (late early Hemphillian) biota from northwestern Kansas: National Geographic Research, v. 6, no. 2, p. 231-244.
Van Couvering, J. A., Castradori, D., Cita, M. B., Hilgen, F. J., and Rio, D., 2000, The base of the Zanclean Stage and of the Pliocene Series: Episodes, v. 23, no. 3, p. 179-187.

Wallace, S. C., 1997, Mammals of the Rhino Hill West local fauna, Miocene (Hemphillian), Wallace County, Kansas: M.S. thesis, Fort Hays State University, Hays, Kansas, 142 p.

Walsh, S. L., 2005, The role of stratotypes in stratigraphy-Part 3, The Wood committee, the Berkeley school of North American mammalian stratigraphic paleontology, and the status of provincial golden spikes: Earth-Science Reviews, v. 70, p. 75-101.

Ward, P. A., III, Carter, B. J., and Weaver, B., 1993, Volcanic ashesTime markers in soil parent materials of the southern plains: Soil Science Society of America Journal, v. 57, p. 453-460.

Ward, P. A., III, and Carter, B. J., 1998, Paleopedologic interpretations of soils buried by Tertiary and Pleistocene-age volcanic ashes-South-central Kansas, western Oklahoma, and northwestern Texas, USA: Quaternary International, v. 51-52, p. 213-221.

Wood, H. E., Chaney, R. W., Clark, J., Colbert, E. H., Jepsen, G. L., Reeside, J. B., and Stock, C., 1941, Nomenclature and classification of the North American continental Tertiary: Geological Society of America Bulletin, v. 52, p. 1-48.

Woodburne, M. O., 1977, Definition and characterization in mammalian chronostratigraphy: Journal of Paleontology, v. 51, p. 220-234.

Woodburne, M. O., 1996, Precision and resolution in mammalian chronostratigraphy-Principles, practices, examples: Journal of Vertebrate Paleontology, v. 16, p. 531-555.

Zakrzewski, R. J., 1981, Kangaroo rats form the Borchers local fauna, Blancan, Meade County, Kansas: Transactions of the Kansas Academy of Science, v. 84, p. 78-88.

Zakrzewski, R. J., 1988, Plio-Pleistocene rocks, Borchers badlands, Meade County, southwestern Kansas: Geological Society of America, Centennial Field Guide-South-central Section, p. 69-74.

Zakrzewski, R. J., 1990, Biostratigraphy of fossil mammals from the Ogallala (Miocene) of north-central Kansas; in, Geologic Framework and Regional Hydrology-Upper Cenozoic Blackwater Draw and Ogallala Formations, Great Plains, T. C. Gustavson, ed.: University of Texas at Austin, Bureau of Economic Geology, Symposium Publication No. 6, p. 98.

Zakrzewski, R. J., 1991, New species of Blancan woodrat (Cricetidae) from north-central Kansas: Journal of Mammology, v. 72, p. 104-109.

Zeller, D. E., ed., 1968, The stratigraphic succession in Kansas: Kansas Geological Survey, Bulletin 189, 81 p.

\section{KGS Stratigraphic Nomenclature Committee}

This paper was completed by current members of the Kansas Geological Survey's Stratigraphic Nomenclature Committee, which was re-established in July 2005, to address stratigraphic issues and establish formally accepted stratigraphic nomenclature for Kansas. The Stratigraphic Nomenclature Committee is the official arbiter of stratigraphic nomenclature and issues in Kansas, subject to review by the State Geologist. More information about the Committee and Kansas stratigraphic nomenclature is available at http://www.kgs.ku.edu/General/Strat/index.html.

The Kansas Geological Survey (KGS) recognizes Zeller (1968) as the current accepted guide and chart for Kansas. Revisions are based on the principles that nomenclature changes will follow the North American Code of Stratigraphic Nomenclature (2005), and changes will conform to international stratigraphic nomenclature standards as they apply to Kansas. 